No 3708

Studia nad Autorytaryzmem i Totalitaryzmem 38, nr 1

Wrocław 2016

DOI: $10.19195 / 2300-7249.38 .1 .1$

\title{
JAROMÍR MLÝNEK
}

Uniwersytet Opolski

\section{Roma criminality in Slovakia. An introduction to the problem}

\section{Introduction}

The least popular national minority in Slovakia are Roma. Cohabitation with this ethnic group is becoming ever more conflicting. Even if we often say that this is a community of people with a great talent for music, they do not know how to play and sing in our common orchestra of nations. They struggle to learn to play by the sheet music that we have been teaching them for decades. The majority community, in our case Slovaks, in the role of a teacher and Roma in the role of pupils often get on each other's nerves. It is difficult to say which of the two parties contributed more to the fact that the relations between Roma and the rest of society can be graded almost as Failed. I was one of the founders of the Romani Culture Department established at the Faculty of Pedagogy in Nitra back in 1992. Having had many conversations with Roma I found out that they lack self-criticism and objectiveness in their statements saying: we are marginalized, you see all our flaws under a looking glass and you measure it by a different meter. Let us suppose that these statements are true. Let us suppose that the power of prejudice is so strong that we lose our ability to differentiate between Roma living the socalled "Gypsy life" and other Roma.

Even though integrated families do not claim that their living standard is lower than that of their fathers, they still feel discriminated against, because the prejudice against them is very deeply rooted. As long as this prejudice exists, Roma cannot become equal people. We can declare that Roma are equal and enjoy the same rights, but these are no more than just concepts we speak of or write about. These are just claims for the eyes and ears of members of the European Parliament - it is a facade. The marginalization is often caused by prejudice of the majority population, but often times it is supported by the way 
Roma live their lives. An important role in creating a negative image of Roma is played also by mass media which often directly link Roma with criminality and other undesired societal phenomena. According to the psychological research, Roma are a specific group of people. In Slovakia they are perceived as a genetically risky group and represent a population that is both genetically and socially strictly isolated ${ }^{1}$. Challenging the civil principle and emphasizing the ethnic or nationality principle often results in the majority society creating generalized associations. Such created xenophobic prejudices are then reflected in tense relations between Roma and non-Roma population.

Poor financial situation, social conditions, social status and often related criminal offenses committed by Roma are a result of several factors. First of them is a long history of isolation caused by the centuries-old rejection of Roma by the rest of society and their gradual social and civilizational isolation. This also led to the development of other factors. Poor housing conditions, often with no access to electricity, and large-size families sharing the same home had a negative impact on the quality of family environment.
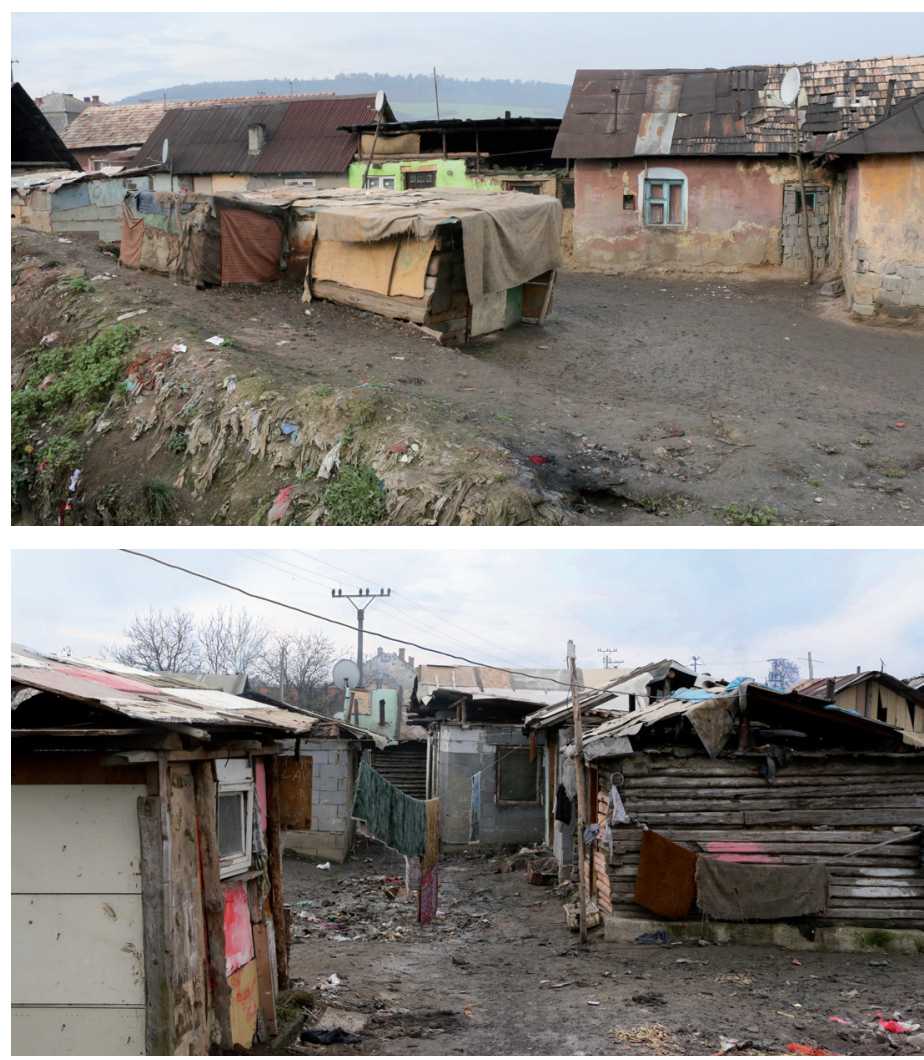

Phot. 1-2. Quality of life in Jarovnice (Prešov district)

Source: own sources.

1 Source: http://www.per-usa.org/reports/StatePolicies (obtained: 1.09.2015). 
Children from such families are insufficiently motivated to regularly attend school and become educated. This is ultimately reflected in the low level of education and low skills, which makes it difficult for them to succeed in the labor market. Customs and traditions of Roma also strongly influence their behavior. A significant part of Roma living in segregated or separated settlements but also part of Roma living in concentrated neighborhoods live only for the present - they are not concerned about the future or their long-term prospects.

The greatest difference between Roma and the majority society is not the color of their skin, but rather different principles of social organization, different way of thinking, different value system, different life strategies and standards governing their social life.

The purpose of this paper is to present the way of life of Roma and the crimes associated with such a life, and to try to identify the reasons why these crimes are commited as well as to deal with different types of crime committed by Roma and their mutual relations.

\section{Crimes of the majority population against Roma}

Crimes related to the Roma minority can be divided into three groups crimes committed by the majority population against Roma, crimes committed by Roma outside their own communities and crimes of Roma within their own community. One important factor to consider when assessing criminality is the situation in the society and the relation of the majority towards Roma community.

There is a prevailing negative view of Roma by a part of the majority population, where mainly due to an increased crime relapse rate of a part of the Roma community the criminality problems are generalized and believed to regard all Roma. Unfortunately, these views can also be observed in some discriminatory practices of state officials. Long-term concerns lead to segregation and separation transforming even into xenophobia and racial intolerance of a part of the majority society against all anthropologically different individuals.

We are seeing manifestations of discriminatory practices especially in relation to employing Roma and also to preventing them from entering restaurants or clubs, often without any legal or other relevant grounds, but many times based on bad past experience. There are also occasional attempts of some mass media to give publicity to Romani criminality, or to marginalize, i.e. "label" them (addressed by the Ethnic Affairs Project). In larger cities, there is reported incidence and activity of extremist movements - in our country it is especially the SKINHEAD movement and various nationalist groups with anti-racist and nationalistic agenda targeting not only Roma, but also other anthropologically different people.

Crimes committed by the majority population against Roma are often linked with racially motivated behavior. The concept of "racially motivated behavior" 
from the penal point of view includes a large number of socially unacceptable behaviors described in the Criminal Code 300/2005 Coll.

To understand the problem of racially motivated crime we should clarify the concepts of race, racism and racial discrimination ${ }^{2}$. Race is an anthropological term, related to the differentiation of human species. It is a set of common inherited traits (morphological, anatomical etc.) characteristic for a certain group of people (three main races - Caucasian, Mongoloid and Negroid $)^{3}$ - a population or a group of populations with a characteristic genetic make up (frequency of genes or chromosome set), which is different from that of other groups, but is able to cross-breed with them at any time.

According to sources, racism, ethnicism and linguicism are defined as ideologies, structures and practices used to streamline and reproduce the unequal distribution of power and resources, both material and non-material, among groups defined based on the principle of "race", ethnicity (culture) or language.

Racism springs primarily from ignorance and the lack of knowledge of the lifestyle and way of thinking of other people. No person is born a racist - the adoption of such beliefs is definitely influenced by their surroundings, family, friends and the atmosphere in the society.

Biologically-based forms of racism brought together carefully selected visible or less visible objective biological characteristics. These served as determining criteria for "races". Several psychological characteristics were then attributed to the respective races. These were hierarchically arranged based on the perception of "their" psychological characteristics. Some races were considered to be more fit for ruling than other. Races and their thus socially and ideologically constructed characteristics have been used to legitimize the unequal distribution of power and resources among races. The ideology of biological racism legitimized control and exploitation of other races by the "white race".

In most countries, biologically-founded racism is being replaced by more complex forms of racism, ethnicism and linguicism. They use ethnicity, culture and language of various groups as a determining criterion and a basis for building hierarchies.

Currently, nobody (openly) claims that certain races are more fit for ruling than others. Today, it is particular ethnic groups, cultures and languages, which are said to be fitter for ruling, development and study. According to this new claim, it is argued that those ethnic groups, cultures and languages that survive and spread succeed only because they are better adapted to modern life - they are more developed. They have greater development potential than other groups. Consequently, the ruling groups would provide less or no chances for the other ethnos, cultures and languages to survive. This is done through institutionally

2 J. Dworzecki, M. Ondicová, J. Mlýnek, Słowacy wobec wybranych patologii społecznych, Pszczyna 2013, pp. 63-116.

3 T. Šišková, Výchova k toleranci a proti rasismu, Praha 1998, p. 62. 
controlled measures such as access to education. Majority language thus appears to be more viable.

The available knowledge brings us to the realization that racism is seen here both ideologically and structurally. Racism does not arise only from a group of malicious, ignorant, uninformed people; it is not only formed by attitudes and prejudices of people against other individuals. Racism is not only a problem of information; it is not linked only to economic or political structures that would continue to exist through institutions, regardless of the ideas and attitudes of people. "Racism is perceived as a combination of ideology, structures and practices"4.

When discussing racism and the Roma community, the notion of "racial discrimination" is frequently used. Racial discrimination is a violation of international law rooted in any differentiation, exclusion, limitation or priority treatment based on race, color of skin, nationality or ethnic origin whether the aim shall be termination or limitation to recognition and execution of human rights and basic freedoms in all areas of public life ${ }^{5}$. Discrimination may include intentional acts towards a representative of a handicapped group, e.g. depriving the person of access to public premises, rejecting a person for his/her color of skin.

On the other hand, attention will also be paid to positive discrimination, since in some areas of life, positive stimulation of Roma citizens may be interpreted as a measure that will eventually lead to positive discrimination.

Social changes, inevitable in the case of the Roma minority, must reject confrontation and create an atmosphere of cooperation and solidarity; rejecting intolerance and racism, and racial discrimination between the majority and Roma.

Citizens in the majority often misuse intellectual immaturity, social reliance, or material need of a significant portion of the Roma community both on an individual basis and also through various business enterprises. They offer loans to Roma with inadequate, often usurious interest rates knowing that this group of socially disadvantaged people will not be able to pay them back. As a result, these businesses distrain flats, real estate or other material assets based on the violation of contractual terms of references. Pawnbrokers operate on a similar principle - they offer minimum cash amounts for objects of value that Roma bring to pawn, and if the amount is not paid back quickly, the pawned object becomes the property of a pawnbroker.

Another type of criminal offense committed by the majority against the Roma minority is involvement in prostitution in which the majority citizens plunder by organizing street prostitution and sexual services offered by Roma women and girls (often minors), misusing their drug dependency.

Roma are not only impaired or victims of racially-motivated criminal offenses but they are the object of a whole spectrum of discrimination in our society that cannot be classified under one of the crimes listed in the Penal Code. Discrimination

4 T. Skutnabb-Kangas, Jazyk, gramotnost' a menšiny, Bratislava 1995, p. 15.

5 K. Košková, Všeobecný encyklopedický slovník M-R, Praha 2001, pp. 11-19. 
and segregation, along with demonstrations of intolerance, do occur almost in all areas of our society and we do not cover all the areas of discrimination in this paper.

Segregation is present already at elementary schools, where parents of the majority population forbid their children from playing with Roma children, stating that they are dirty, stinky and that they steal. Such a generalization creates an artificial barrier of isolation, intolerance and negative attitude towards Roma children already among children. Discrimination can be observed at schools, mainly in lower grades where children are seated separately, while discrimination may also be promoted by attitudes of some teachers.

In higher grades of elementary school, labelling-marginalization of Roma children is demonstrated also through a certain type of aggression. It is rather an exception when a class does not make a Roma pupil an outcast. This is one of the reasons why Roma parents only rarely send their children for school trips or outings etc. Racial segregation of Roma is evident in many areas in Slovakia: separate schools established for Roma; children mainly from settlements placed directly into special schools without proper testing. Stronger xenophobic trends and racially-motivated demonstrations of violence against Roma children are present at higher grades of elementary school but mainly at apprentice schools. In reaction to segregating the two communities, the Roma children and youth lose trust towards the majority youth. Many teachers who are to teach Roma children do not educate pupils in a proper sense. In reality, their teaching consists of playing a tape recorder with music after children come to school so that they dance. It is quite common that Roma children cannot even sign their names after finishing elementary school. Some schools have prevented Roma children from participating in after-school activities, justifying it with the fact that the Roma children will not have their lunches paid. When the project of social benefit cuts in favor of payment for the lunch of the children was launched, Roma children ate in a separate room, segregated from other children. Re-education of Roma is not enough; it needs to go hand-in-hand with educating the majority society towards tolerance and reciprocal communication.

Even though mandatory military service is now history, we can conclude that racial and ethnic prejudices also emerged in military service. Frequently, indoctrinated followers and fans of the Skinhead movement joined the military. Bullying and physical attacks against Roma soldiers occurred in closed squads or groups of trainees, mainly during free-time periods with no military commanders-professionals around.

Sometimes, Roma are exposed to aggressive actions by police forces during personal checks or investigations. Either a police officer acts aggressively against Roma or he/she is trying to investigate a certain criminal offense using inappropriate investigative methods while doing so. The situation is becoming even more extreme since Roma even when beaten do not report such events out of fear of being beaten up again. Generally, there is a growing fear and distrust among Roma towards the Police Corps. Many police officers are aware of the fact 
that Roma will not file complaints against a police action due to their low legal awareness and absent knowledge to whom and where they should complain or how to proceed. In some cases, a Roma is given a blank sheet of paper that he/ she is supposed to sign under threat of physical violence. Another scenario is that minor Roma pupils are summoned for interrogations from special schools, with no representation by a parent, surrogate, teacher or social worker. Human rights are violated even in those cases when a suspect of a criminal offense lacks fluency in the Slovak language, does not understand the charges pressed against him/her, thus being unable to file an adequate objection. In many such cases, even when pursuant to the provisions of the Slovak Constitution the suspect is entitled to an interpreter, the investigator will not call for one. Cases have been reported of young police officers being fans of far-right tendencies. With a view to eliminate this serious situation, it is vital to respect the binding character of the results of psychological tests that are part of entry exams for applicants to join the Police Force, namely with regard to disposition to aggressiveness. It is imperative to thoroughly examine: possible membership of an applicant in a far-right or far-left organization; whether he/she has established active connections with members of such organizations; whether he/she is connected to a criminal circle; whether there is an inclination towards alcohol or drug abuse; or whether he/she is a gambler. It is vital to examine a person's motivation for choosing policing as a profession. Testing of applicants must be vigorous, not formalistic as it has frequently been so far. If circumstances so require, records from private mobile phones should be requested in order to verify whether an applicant has been in contact with individuals with a criminal background. It is important to pay more attention to training and education on human rights and communication skills, especially for newly-hired Police Corps members. Training and education of young police officers must focus on practical situations/scenarios that will occur during their future service, especially through role playing/mock investigations. Emphasis must be put on training concerning assertive behavior and risk, stress and conflict management. Regarding the protection of the rights of Roma, a network of activists focusing on human rights protection should be built from among Roma who would then advise individuals who have suffered some damage and would also increase their legal awareness.

A pilot project of police specialists working with communities, launched in 2004, was designed to connect with other existing programs from other fields, such as social field work projects, and to create positions of police specialists who will perform a certain set of activities as members of the Police Corps.

There are also clear signs of discrimination in the judiciary. Many judges trivialize racially-motivated attacks (hate crimes) if the victims are Roma. Representatives of the General Prosecutor's Office in the Slovak Republic have confirmed this situation on various occasions. There is a well-known case in Michalovce of one pub that is famous for not "welcoming" Roma, with the staff actually 
preventing Roma from entering. The District Court in Michalovce partially supported the claim made by the Roma petitioners; however, the ruling is ambiguous. On the one hand, the verdict concluded that there had occurred discrimination against the petitioners and ruled that the owners of the pub must send a letter of apology for the discrimination. On the other hand, the court ruled there had been no discrimination based on Roma ethnicity because the owner reportedly had routinely served other Roma at other times. The court's ruling did not specify what kind of discrimination had actually taken place ${ }^{6}$.

Hidden forms of racism, often more dangerous than open racial violence, are discernible in employment. After businesses seeking new employees find out that a job seeker is Roma, they quite frequently announce the position had already been taken. Another situation is when an employer, receiving applications from multiple job seekers, prefers a non-Roma applicant even if a Roma applicant meets all the eligibility criteria or is even better at some of them. Employers usually do not provide any justification in these cases. These kinds of actions require amendments to the Labour Code to ban any form of discrimination. Those activities, however, cannot be facilitated by the Police Corps. They will require active involvement of labor inspection officers or other appropriate authorities. This area will also require raising legal awareness of both enterprises and Roma. The significant cuts in social benefits introduced by the Dzurinda government did not increase Roma employment.

Currently, many Roma see leaving the country to find work abroad as a potential solution to their difficult situation here (going to the Czech Republic, England, the Netherlands, or Ireland). After returning to Slovakia, they often offer financial assistance to their relatives while they seek to integrate themselves with the majority population.

Registering a permanent address was a nation-wide problem in which racial motivation was the underlining decisive factor in decision-making by public administration. As a result of rural-urban migration and aging, there are many vacant houses in a number of villages. If the applicants for permanent residence were Roma the mayors would not let them receive permanent residency in such dwelling; nor would they offer the vacant house for sale to the Roma. A potential solution would be raising awareness among the citizens, including mayors, and enhancement of tolerance. A possible incentive could be offering tax relief to the municipalities welcoming Roma applicants for permanent residency or offering financial aid to Roma striving to integrate into the majority population for the purchase of abandoned houses without owners. Due to Slovakia's accession to the European Union social changes are reflected in revised legislation at the European level. Therefore, applying for permanent residency is currently much easier and it is expected that discrimination will cease to exist in this area.

${ }^{6}$ Source: http://www.rasizmus.sk (obtained: 1.06.2014). 
Discriminatory trends are also evident in public procurement and competitions. Businesses and state companies implementing their decision-making powers unilaterally rule out an applicant who is found to be Roma, disregarding the guarantees and quality of a bid. A potential solution may include stricter control over public procurement or competition and sanctioning racially-motivated decisions by a selection committee. Such a measure needs to go hand-in-hand with improved awareness of Roma entrepreneurs on how to proceed in such manipulated tenders.

Political party leaders and representatives of local self-governments illegally manipulated elections, following a motto "Roma ballots don't stink on election day". Prior to elections, political candidates would visit Roma settlements, misusing the illiteracy, low level of awareness and poverty of the citizens, canvassing voters with a promise of alcohol, cigarettes or food, asking for votes for them or their political parties.
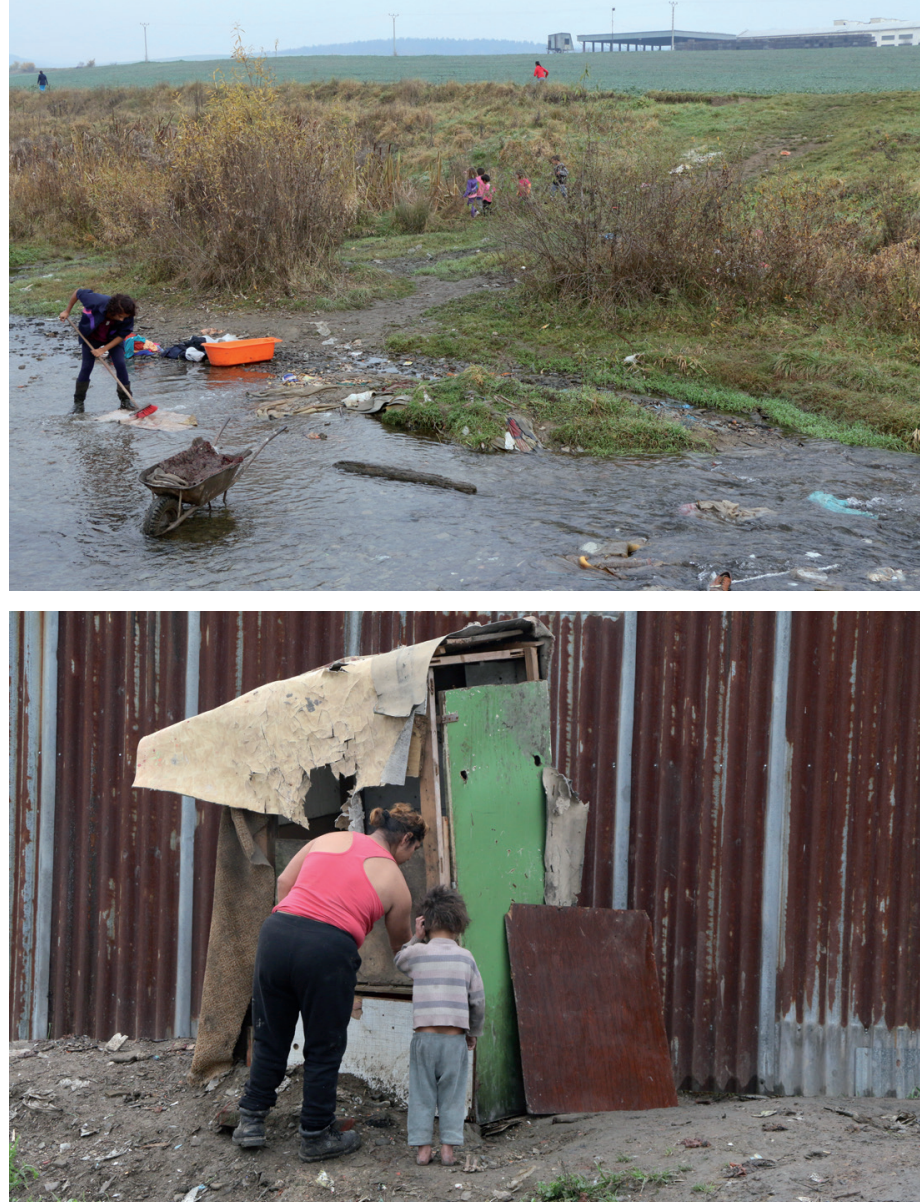

Phot. 3-4. Sanitary conditions in which Roma live in Jarovnice (Prešov district) Source: own sources. 
It would be worthwhile to examine whether the above action does not represent a criminal offense pursuant to Section 351 of the Criminal Code - Obstruction of the Preparation and Holding of Elections and Referendums. In order to prevent manipulation of the free will of voters, it would be necessary to find out what the role of Roma loan sharks is in these activities and their connections mainly to local self-governments. When persons running for election do offer donations like alcohol, cigarettes and food, the source of funds used for this purpose should be examined. The international community should monitor these illegal pre-election activities through international monitoring bodies and site visits to the highest possible number of Roma settlements prior to September, e.g. prior to the elections, through another visit by the Committee for Racially Motivated Crime.

The negative position of Roma in health care is predominantly a result of high unemployment and non-payments (non-existence) of health insurance. The poor condition of health care in Roma settlements translates into the fact that when visiting those settlements one can rarely see a Roma above 50 years of age. According to the statements of some Roma, child mortality also ranks high. In some health-care facilities, health-care professionals are reluctant to examine Roma from a settlement, mainly due to neglected hygiene. Accessibility to emergency health-care services in the settlements, especially those isolated from the municipalities often without electricity supply, or any other connection to a healthcare institution is a very serious problem. A potential solution could be special health-care services for Roma in settlements. This is a task for the Ministry of Health, closely cooperating with health insurance companies, particularly Všeobecnázdravotnápoist’ovňa, Slovakia's largest insurer. Considering this situation, training of 150 Roma field health workers has been a move in the right direction even if this number is far from sufficient; it is necessary to recruit almost 400 health-care workers.

Discriminatory practices can be observed in provision of services in various other areas. Preventing Roma from visiting restaurants or pubs is one example. Some supermarket owners and hypermarkets have ordered private security services to limit the number of Roma entering the premises to one at a time, even disregarding whether it is a couple or a parent with a child. This routine only allows one Roma in and once he/she is finished shopping and leaves the premises, security personnel allows another Roma to enter. As a result, Roma shop in more distant parts of the city and often they need to use public transportation when doing big shopping.

Another example of discriminatory practices can be seen in public transportation - drivers only check Roma for transport tickets and they do not use courtesy, disregarding the age of the passenger. Similar racial discrimination by public transport drivers against Roma can be observed in cases of request stops in areas with a large population of Roma. When a majority citizen requests a bus to stop, the driver stops; when a Roma requests the vehicle to stop, the driver frequently 
does not do so. In some cities checking bus tickets is targeted exclusively at Roma commuters.

A serious violation of basic constitutional rights of Roma is reported information that Roma in some villages in eastern Slovakia are prevented by local priests from entering churches, probably mainly Roman Catholic churches. A prevailing negative feature in their activity includes reporting of the ethnic origin of criminal offenders, violating civil principles. This kind of approach significantly encourages racial and ethnic hatred while seriously violating Slovakia's privacy act.

As stated above, this text does not cover all areas of discrimination in social life based on ethnicity or biological differences. Still, the areas described above clearly demonstrate how difficult the situation of Roma is in Slovak society. Hostile attitudes toward Roma, often expressed also by official institutions, result in an embittered attitude of Roma towards the rest of society and a lack of trust while a significant part of the majority society continues to hold on to its segregationist and separationist tendencies against Roma.

\section{Roma criminality against the majority population}

Roma criminality outside their communities is a commonly discussed topic among the public. When examining this issue, it is imperative to consider various perspectives. Offering the statistical interpretation of the topic would be easy - it would be enough to publish the number of criminal offenses in certain periods. However, such an interpretation is unethical and does not respect legal requirements. Thus, it is first vital to examine the causes and only then combine those findings with the described criminality committed by Roma outside their communities.

Roma criminality against the majority population is influenced by the situation inside the Roma community, including a very unfavorable health situation, especially of Roma living in isolated settlements or in communities adjacent to some villages. Children run the highest health risks, with no prevention organized by health care institutions, a higher level of infectious diseases among Roma than other citizens, emergency housing conditions with big families residing in the dwellings - a dwelling being understood here as something transitory, tempor$\operatorname{ary}^{7}$ - which relates to: the absence of standard hygiene; a low level of education among children and youth; a low level of training and education required for various professions resulting in uneven opportunities in the labor market and high levels of unemployment; prevalent socio-pathological events mainly among Roma living in an underdeveloped environment; frequent alcohol abuse, gambling, recently drug abuse; a high level of recidivism among some Roma who have already

\footnotetext{
${ }^{7}$ I. Radičová, Hic Sunt Romales, Bratislava 2001, pp. 56-75.
} 
committed a criminal offense; a higher prevalence of aggressive behavior, small robberies, frauds and other types of criminal offenses within the Roma community that demonstrate tension among Roma families.

Many Roma rely on the state to take care of them; there is a low level of awareness of their own origin, while some proportion of Roma intentionally declare their Roma nationality only in certain circumstances. It is detrimental that Roma who have overcome the barrier of separation from the majority society, received education and achieved some status are ashamed to declare their Roma nationality - due to existing reasons and partially based on unjustified negative attitudes towards Roma. Fragmented positions and opinions of the Roma community, enforcing individual interests at the cost of the whole community, i.e. links between speculators and immature members of communities and their abuse; negative stereotype of the life of Roma, understanding and organizing of life on the day to day basis, lacking the ability to plan things ahead (absence of social planning skills) represent further problems. A significant part of the Roma community are not ready for a market economy that requires personal participation of every single individual in creating preconditions for successful inclusion into society and responsibility for one's own life; real and functional illiteracy of adults, a very different hierarchy of values of some proportion of Roma, result primarily from their different lifestyle.

One of the important factors is Roma employment. Employment and a stable income have the biggest impact on criminality — the so-called survival behavior ${ }^{8}$, meaning committing criminal activities for the sake of survival. In this context criminality is understood as criminal activity undertaken by Roma to obtain commodities and assets with a view to providing for the daily needs of their families (various burglaries in shops, houses or chalets; thefts of forest wood, agricultural crops, animals). Until 1989, the socialist regime managed employment through "unemployment behind the walls of the factories". This method of "employment" was applied across the nation, also for Roma. After 1989 most Roma became "redundant" and of little use to the new economy, not having anything to offer in a labor market with increasing requirements for skills and knowledge. The Roma community socially closed up which has resulted in social exclusion. Important drivers generating financial resources include employment of both partners in the family. Such a model, however, is not the preferred one in the Roma community. By custom, Roma women stay home with their children ${ }^{9}$.

There have been many public opinion surveys on the potential improvement of this unfavorable situation. A survey of the Institute for Public Affairs of September 2001 indicated a high level of pessimism among Slovak citizens. Almost $85.5 \%$ of the respondents believed it is probable or rather probable that Roma

\footnotetext{
${ }^{8}$ Source: http://www.per-usa.org/reports/StatePolicies (obtained: 1.09.2015).

9 M. Vašečka, Súhrnná správa o Rómoch, Bratislava 2002, p. 43.
} 
criminality would rise; $87.5 \%$ expected significant growth in the Roma population; and $82 \%$ thought it was probable or rather probable that Roma employment was not going to rise. The situation in 2004 was much worse than in 2001, with the situation in eastern Slovakia from February 2004 being a good example. There was a wave of Roma unrest that could be partially linked to cuts in social benefits. This wave of unrest resulted in criminal behavior of Roma, namely violent burglaries in shops and looting.

The security situation related to Roma criminality against majority inhabitants is also changing due to other factors, such as societal changes, political developments, and the social and economic situation - all these factors have an impact on criminality. Changes in society go hand-in-hand with changes in the character of criminality - from simple criminality to more complex cases (e.g. multiple frauds). Thus, the possibilities for Roma to commit criminal offenses are becoming more limited since they mostly commit "simple" offenses such as thefts, bodily harm, violation of freedom of dwelling, and disorderly conduct.

There is one significant factor influencing Roma criminality outside their community - it is a need for ongoing financial income to support their families. A significant proportion of Roma criminality outside of their communities is often preconditioned by criminality occurring within their communities.

\section{Criminality within the Roma community}

Roma criminality within their own community includes diverse criminal offenses. Examples of violent criminality include offenses of bodily harm, robberies and blackmailing that are closely connected with alcohol abuse, sniffing and drug use. Examples of criminality related to corruption of morals include rape and sexual abuse, while the actual situation is dramatically different than the number of reported cases - due to the so-called latent criminality.

Latent criminality is an important notion from the perspective of criminality itself, its scope and forms and also from the preventive point of view - and its prospects to impact criminality. Latent criminality is hidden, unreported and not registered by the police. The police do not know about it. Frequently, a minor Roma girl becomes pregnant but she does not indicate the father of a child out of fear from her boyfriend or from him potentially abandoning her. Statistically, the most represented types of criminality are property offenses - petty burglary, burglary of shops and restaurants, and thefts of belongings from cars. Many Roma commit this type of criminal offenses due to the lack of money or are encouraged by unpunished cases of criminality in their community. Older Roma often misuse minors for pickpocketing. Recently, there have been instances when Roma have damaged public facilities by dismantling electric poles, taking the iron components to scrapyards, while exposing themselves to danger. Economic criminality is 
not as strong as other types of criminality, however, Roma are often misused by Roma speculators for various economic and loan frauds. The corruption of morals is closely connected with the above-mentioned value system of the Roma.

\section{Corruption of morals}

In addition to what has been mentioned above, criminal offenses of sexual abuse pursuant to Section 201 of the Penal Code or intercourse between direct relatives pursuant to Section 203 of the Penal Code are frequent. There have been cases of intercourse between a father and a daughter, a mother and a son ${ }^{10}$ or between siblings. In the worst scenario such actions result in pregnancy. A different value system has also resulted in corrupting the moral upbringing of juveniles (a criminal offense) pursuant to Section 211 of the Penal Code, with education ranking as the lowest upbringing priority.

Roma often do not send their children to school because they believe it is not necessary. Education is not a value for them. Currently, the main criminal activity is usury and related criminal offenses. A lack of integration of the Roma community into the majority society is usually given as the major reason underpinning this problem. This primarily includes challenging living conditions, mostly in underdeveloped communities and socially-disadvantaged families whose members are financially dependent on social benefits with a significant number of them incapable of planning their expenses. Society is striving to solve this problem through a wide spectrum of activities. Unfortunately, state efforts are frequently in vain because there are many individuals who misuse the poor social situation of these groups and sponge off them. An example of this is usury, mainly among Roma citizens living in communities. Usury, i.e. lending money at a high, often $100 \%+$ interest rate, flourishes wherever there are favorable conditions for it - many poor people without cash or with small savings, needing cash to survive, or, which is typical for the Roma community, needing cash for alcohol and cigarettes. Money lending is very well organized. A loan shark lends money at the time of the greatest financial distress and the debt is paid back when either social or other benefits are received. Often, the loan shark waits at the post office or at the bank to collect the repayment together with together interest, while the victim of the loansharking has practically no other chance but to pay the money back and he or she ends up in a situation where they need to borrow money again. Upon defaulting, the money is extorted forcefully. The victims are usually intimidated and if they do not pay the money back, the interest rates are usually increased through the so-called interest on interest, which is again usually at the level of $100 \%$.

10 This situation is especially serious in Rudňany municipality, where genetic damage has been observed in a significant portion of children. 
This situation generates a long-term and deepening dependency of many Roma families on loan sharks. The whole system is based on their inability to pay back the loan. Usury in the Roma communities has reached an unprecedented scale and it economically weakens already socially-weak families. Usury has very serious consequences and represents a real threat to the victims of this criminal activity, including a serious potential threat to the state. Loan sharks are often well situated, with a significant impact on a particular region.

While in some municipalities loan sharks drive old cars of low value, quite frequently one can see a loan shark driving an expensive foreign car. Inclusion of the Roma communities into the majority society is complicated mainly by the fact that they live in a socially-disadvantaged environment with their members being financially dependent on social benefits and mostly unable to manage their funds. Such communities are the main source of income for loan sharks, being a breeding ground for scaling up their activities.

The aggrieved parties, regardless of the large amounts of money they lost causing them to fall into poverty, are frequently unwilling to cooperate with the police; in many instances it is so because they are afraid of ongoing threats and violence from the usurious party. In certain instances the unwillingness to cooperate is grounded on fears that they would not receive another loan. Occasionally it happens that the aggrieved contact the police and announce the criminal act of usury but then they keep modifying their statements and testimonies, or withdrawing them or otherwise mar police action.

Investigating a criminal act of usury requires testimony presented by a witness, the aggrieved party, and without cooperation of the aggrieved party it is very demanding to prove this kind of crime and the entire criminal evidence presented by the police becomes significantly difficult in that way. Perpetrators of usury are often well-off people, those who have much influence on what goes on in a specific region.

The police, when seeking to identify usury, must draw on two essential aspects: first, the level of development of a region where the Roma settlement is situated; and secondly, the kind of settlement. The latter criterion determines the choice of the tactic the police will need to use. There are the following kinds of Roma settlements in Slovakia.

There are settlements that are actually a separate urban whole that is physically detached from the municipality and is in fact an independent unit. They are often situated several kilometers away from the nearest municipality. A characteristic example is the Roma settlement in the municipality of Letanovce (Spišská Nová Ves district) or the one in the municipality of Rakúsy (Kežmarok district). In certain instances these settlements are not connected to the basic municipal infrastructure. The settlement in the municipality of Ortut'ová (Bardejov district) is not even connected to electric power mains. 
There are settlement formations that are situated at the margin of a certain municipality but their residents are usually not socially or economically integrated with the municipality - independent settlement formations within municipalities. These are most usually separate streets of neighborhoods that, in urban terms, are integral parts of municipalities but with regard to social and cultural aspects, they are independent entities. A characteristic example is the settlement in the municipality of Hermanovce (Prešov district) that is situated in the lower part of the municipality, on a separate island between two brooks, and the municipalities of L’ubica (Kežmarok district), Kurima (Bardejov district) or Spišský Hrhov (Levoča district) where Roma are concentrated in certain streets.

There are municipalities with the Roma population dispersed among the majority population. A characteristic example is the municipality of Nová Lesná (Kežmarok district) with most Roma living dispersed in the community and simultaneously being fully integrated with the non-Roma with houses that do not differ from the houses of the majority population. However, the fact that the Roma residents are dispersed within a municipality does not automatically mean that the community is integrated with the majority population.

Municipalities with an absolute or dominant share of Roma in the population. There are only a few municipalities of this kind in Slovakia. One with an almost $100 \%$ Roma population is just a single municipality, namely Lomnička (Stará Lubovňa district). Significant majority Roma populations are in Jarovnice (Sabinov district), Jurské (Kežmarok district) and in several others.

City ghettos with a significant or absolute share of Roma in the population. These are settlement formations with an outlined urban space, often also physically separated from the surrounding city parts/neighborhoods. The notorious Roma ghetto in the Košice city part is known as LUNIK IX and the Dužavskácesta neighborhood is in Rimavská Sobota. The housing stock in these neighborhoods usually is in a severely dilapidated condition, often almost unfit for use at all (demolished common areas, torn out floors, damaged sewage systems, water pipes and power cables, missing or damaged main door and similar indicators of neglect). Experts call housing units in such a poor condition "stripped apartments".

The estimated prevalence of usury in these kinds of settlements is high, although it is not of all types. It is very hard or almost impossible for an outsider to penetrate the community. Information can be acquired primarily through employees of the third sector organizations operating in the settlements and from Roma activists who have developed a relationship with and won the trust of people in a specific settlement. The police do not display much interest in visiting the settlements and they lack basic data about the population. The police arrive in a settlement only if they need to summon a Roma person. Police officers who specialize in working with Roma communities may be a source of information. 

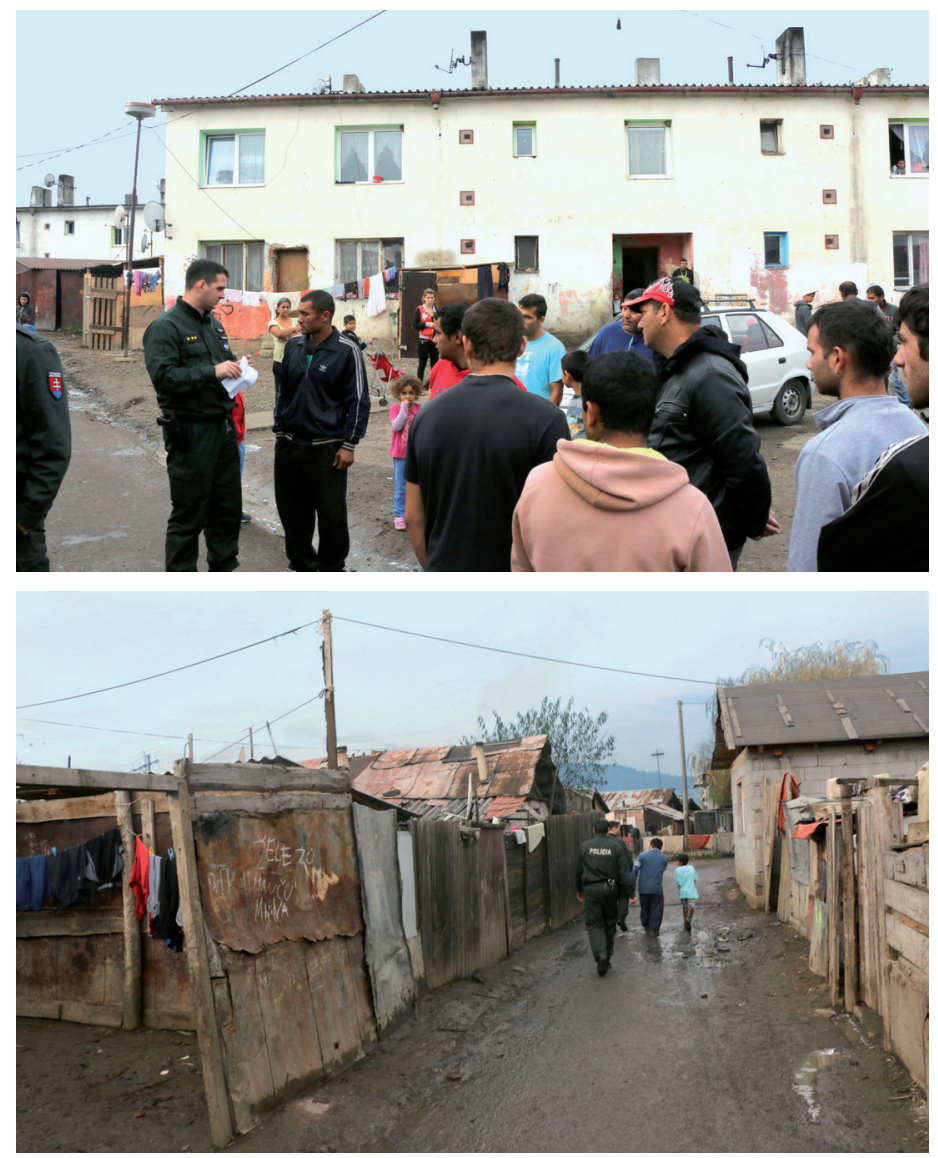

Phot. 5-6. Sanitary conditions in which Roma live in Jarovnice (Prešov district)

Source: own sources.

Preparations are now under way to establish the Roma-specialized police or police assistants, according to the Czech model. When seeking to obtain information about usury, involving the Vajda (chief of the settlement or tribe) must be delicately considered. A source of information about the occurrence of usury could also be trade licenses for providing commercial services, ownership of motor vehicles, and brick houses above standard compared to the rest of the community's houses. The crime can be well documented using audio and video recording devices, providing the action is organized properly and in line with relevant legislation. It is practically impossible to use information-technology means or surveillance in a settlement. Documenting usury with the above-specified means is possible only in the vicinity of post offices where Roma collect their welfare benefits, if the money owed is collected in that particular locale. Information can be acquired from NGO employees and from persons belonging to the most socially-needy strata of the population. 
Independent city parts with higher Roma concentration rates. In this regard several typological models can be distinguished ${ }^{11}$.

Groups living in low standard family houses, usually built in the interwar period, as worker colonies (Prešov - Ulica Čapajevova). These houses were acquired by Roma usually as community houses when they became unattractive to the majority population on grounds of obsoleteness or as houses granted by enterprises to their employees.

Lower standard apartments in apartment houses built in the post-war period (Prešov-Solivar - Ulica Pod Hrádkom) or originally standard apartments in older apartment houses that were not maintained and sank to the lower category housing units (where they rightly belong); (Prešov — Ulica Tarasa Ševčenku, Prešov - Ulica Majakovského) ${ }^{12}$. These apartments were more frequently provided to Roma once they had become socially unacceptable, owing to a poor standard, to the majority population (apartment-based heating, obsolete infrastructure in wiring and pipes, no gas connection and the like).

Apartments in old apartment houses or detached family houses in city centers that had been built between the two world wars or a longer time ago (Prešov Ulica Solivarská).

Modern community apartments in separate apartment houses (Prešov Stará Tehelňa). These are tenant municipal apartments that were built under the government program for housing construction for the socially worse-off population strata for which state budget subsidies could be received for up to $80 \%$ of procurement costs for the construction.

The usury risk is high in the presented typological models. Penetrating these communities is difficult. Information can be acquired from the socially poorest community members or from the third sector workers if they do work with the community. In these communities the assumption is that the role of the Vajda is weak or there are several Vajdas representing family clans. In the instance of usury, the assumption is that the loan shark does not live within the community but lives somewhere else. The opportunities to use information and technology means and surveillance are limited. A good way to document the crime, once the action has been well prepared and in accordance with applicable legislation, is to make audio and video recordings. Instances of usury have been identified with the use of this technology.

Besides the safety aspects of usury regarding the victims of this crime, usury also has a strong adverse impact on the communities and the society. Loan sharks take advantage of the social distress of thousands of families, take advantage of their low education level, the absence of social planning and/or of an extraordinary event in the family (a wedding or funeral) and through their victims tap into the social welfare system. Millions of Slovak crowns in the welfare system in-

11 A. Jurová, 'Riešenie rómskej problematiky na Slovensku po druhej svetovej vojne', [in:] Neznámi Rómovia, ed. A.B. Mann, Bratislava 1992, p. 102.

12 E. Lacková, Narodila jsemse pod št'astnou hvězdou, Praha 1997, pp. 30-61. 
tended for socially-needy and unemployed persons end up in the hands of a few hundred loan sharks. The concentration of large amounts of money in the hands of a few individuals then turns into the legalization of proceeds from crime, tax fraud and other kinds of primarily economic crime.

The situation developed very adversely in 2004, following the adoption of fundamental amendments to social legislation that resulted in lower welfare benefits. Everyone remembers crowds looting shops. Certain contemporary politicians identified loan sharks as the trigger of the phenomenon. Fighting usury, upon societal order, has become one of the priorities for the police, as indicated in Table 1.

Table 1. The number of identified crime acts

\begin{tabular}{|c|c|}
\hline Indicator & Number of identified crime acts \\
\hline 1993 & 5 \\
\hline 1994 & 15 \\
\hline 1995 & 21 \\
\hline 1996 & 22 \\
\hline 1997 & 8 \\
\hline 1998 & 22 \\
\hline 1999 & 19 \\
\hline 2000 & 34 \\
\hline 2001 & 21 \\
\hline 2002 & 43 \\
\hline 2003 & 61 \\
\hline 2004 & 125 \\
\hline 2005 & 35 \\
\hline 2006 (first six months) & 16 \\
\hline
\end{tabular}

Source: crime registry and statistics system of the Police Presidium.

\section{Conclusion}

The data for 2005 and 2006 indicate that the police relaxed their activities, along with less interest in society to address this issue. Under no circumstances can one say that the prevalence of usury decreased in Roma communities. It certainly is a non-systemic move for the police to give up addressing this issue. The Office of the Plenipotentiary of the Government of SR for the Roma Communities highlighted the extraordinary timeliness of addressing the usury issue in the Roma communities as early as in 2004 when the office submitted initiative material for negotiations with the SR government entitled "An Analysis of Usury Crime in Slovakia and a Proposal for Addressing It" that the government took 
notice of. During the comments-giving procedure, prior to submitting the material for discussion in the cabinet, the most closely-related ministries, such as Ministry of Interior and Justice, excluded any substantial proposals for action under their ministries and in the end the material did not assign any commitments to anyone.

A significant negligence committed by the police and other law enforcement bodies in criminal proceedings is that they fail to investigate this crime in a broader context, in association with another crime that is committed as a related/ secondary crime of violence, or of an economic or property-related nature (failure to pay appropriate taxes and insurance premiums, bribery, corruption, bodily harm, extortion, blackmailing and so forth).

\section{Bibliography}

Dworzecki J., Ondicová M., Mlýnek J., Słowacy wobec wybranych patologii społecznych, Pszczyna 2013.

Jurová A., 'Riešenie rómskej problematiky na Slovensku po druhej svetovej vojne', [in:] Neznámi Rómovia, ed. A.B. Mann, Bratislava 1992.

Košková K., V̌̌eobecný encyklopedický slovník M-R, Praha 2001.

Lacková E., Narodila jsemse pod štastnou hvězdou, Praha 1997.

Radičová I., Hic Sunt Romales, Bratislava 2001.

Šišková T., Výchova k toleranci a proti rasismu, Prague 1998.

Skutnabb-Kangas T., Jazyk, gramotnost' a menšiny, Bratislava 1995.

Vašečka M., Súhrnná správa o Rómoch, Bratislava 2002.

\section{Internet sources}

http://www.rasizmus.sk (obtained: 1.06.2014).

http://www.per-usa.org/reports/StatePolicies (obtained: 1.09.2015).

\section{Legal act}

Act 300/2005 Coll. — the Penal Code. 
ROMA CRIMINALITY IN SLOVAKIA.

AN INTRODUCTION TO THE PROBLEM

\section{Summary}

The article concerns the problem of crime related to the Roma minority in Slovakia. The text presents the most important socio-cultural issues that affect the occurrence of crime perpetrated against Roma. It also discusses crime committed by Slovak Gypsies. The paper also comprises photographic documentation.

Keywords: Slovak Gypsies, Slovak Republic, criminality.

Jaromír Mlýnek

e-mail: jaromir.mlynek@minv.sk 